\title{
SAREKAT DAGANG ISLAM (1905-1912): BETWEEN THE SAVAGERY OF VEREENIGDE OOSTINDISCHE COMPAGNIE (VOC) AND THE INDEPENDENCE OF INDONESIA
}

\author{
Muhammad Kaffin Mustakif \\ Student of Program Studi S2 Sejarah Kebudayaan islam \\ Program Pascasarjana UIN Sunan Gunung Djati Bandung \\ Email: kaffin.mustakif@gmail.com \\ Mumung Mulyati \\ Program Studi Perbankan Syariah \\ Fakultas Agama Islam Universitas Islam Nusantara Bandung \\ Email: mumungmulyati@uninus.ac.id
}

\begin{abstract}
Sarekat Dagang Islam SDI (Islamic Trade Union) was originally an association of native Muslim traders. The organization formed by Haji Samanhudi in Surakarta on October 16, 1905, was initiated with the initial aim of gathering native Muslim traders (especially batik traders) to compete with big Chinese traders. At that time, Chinese merchants were more advanced in business and had higher rights and status than other Indies residents. Policies that were deliberately created by the Dutch East Indies government then led to social change due to the emergence of awareness among the natives. This article discusses how the initial formation of this organization by taking a lengthy historical background; that is, since the entry of the Dutch into the archipelago. This lengthy background was chosen so that the birth of SDI could be understood as the culmination of indigenous disappointment and suffering because of the discriminatory policies of the Dutch colonial government, in addition to other awareness arising from aspects of increasing the level of indigenous education and changing the political atmosphere in the Netherlands. Using a literature survey, this article found that the awareness of native Muslim traders who later gave birth to SDI became the forerunner of the overall indigenous knowledge to obtain independence from the Netherlands. It also led to SDI becoming Sarekat Islam (SI) in 1906 and gaining official recognition from the Dutch government on September 14, 1912. This article captures the historical message that progress of a nation can only occur if the components of the country have a shared awareness to forward through the agreement or national consensus that the formulation is also carried out jointly.
\end{abstract}

Keywords: Sarekat Dagang Islam SDI (Islamic Trade Union); Sarekat Islam SI (Islamic Union); VOC Crime; Ethical Politics; Dutch Colonial Government

\section{A. INTRODUCTION}

According to the Oxford English Dictionary (OED), "colonialism" comes from the Latin word "colonia." This word means "agriculture" or "settlement." At first, the word was related to the habits of the Romans who settled in other countries but still retained their citizenship (Simpson, 2009). In its development, this word became a term that was interpreted as a notion to control the sovereign territory of another country (Cheng, 2008, p. 317) to expand and dominate the region of the country, including its original inhabitants (Altbach \& Selvaratnam, 2012, p. 5). Domination occurs in the state, political, cultural, military, and socio- 
economic administration sectors, and especially the exploitation of natural resources (Steyn, 2003, p. 188).

This understanding is the embodiment of a system of values and the belief that the degree of people conquered is lower than that of conquerors. A project of 16 th century white Europeans developed the concepts of racism and ethnocentrism and the theory of Social Darwinism (Hawkins, 1997, pp. 3-58). In the beginning, these concepts and assumptions were used to justify the dominance of the white European population against non-white Europeans. However, this dominance then spread throughout the worl (Dei, 2007, p. 190).

The United Kingdom, for example, once had 43 colonies on five continents (Ingham, 2016, p. 20). Then France followed its colonization which was said to be no less "great" than England (Aldrich, 1996, pp. ixx). Likewise Spain, (Schmidt-Nowara \& Nieto-Phillips, 2005, pp. 1-18), Portugal, (Newitt, 1986, pp. 19), Germany (Smith, 2012, pp. 8-19) and the Netherlands (Nieuwenhuys \& Beekman, 1982, pp. viii-xii). In almost all colonies, life values are based on colonial values (Axtell, 1987) and the priority of all production output values is brought to the colonial state (Settles, 1996).

The term "colonialism" often exchanges meaning with "imperialism" (Bennett \& Hodge, 2011, p. 13) or there is overlapping of meaning (Aneek, 2010, p. 68). Therefore, there is something that equates between the two and some (Jackson, 2009). From the aspect of power, the term "imperialism" has a broader meaning than "colonialism." (Young, 2016, p. 27). However, psychologically, perhaps the term "colonialism" has an impact longer, especially in colonized people (Bulhan, 2015).

Indonesia was colonized by the Dutch for approximately three hundred fifty years (Vandenbosch, 2001, p. 145). Later, the statement gave rise to specific discussions and comments (Absiroh, Isjoni ', \& Bunari ', 2016). This statement attributed to Bung Karno is considered as political propaganda (Anugrah, 2017). However, this propaganda is still regarded as necessary as said, at least, by two historians, in Pratama, (Pratama, 2018) Yerry Wirawan (Sanata Dharma University Yogyakarta) and Roji Nugroho Bayu Aji (Surabaya State University). Wirawan said that the propaganda was expressed to burn the spirit of the struggle of the Indonesian people (in the face of the war of independence [1945-1950] because the Dutch wanted to re-colonize Indonesia). While Aji said that the propaganda was aimed at strengthening the nation because the colonial atmosphere was inherited in the form of pain. That inheritance can be in the form of glory or pain. The way of pain can be more powerful to strengthen the feeling of the same fate to unite.

The discussions and comments about the Dutch colonial period for about three and a half centuries, probably, originated from Gertrudes Johan Resink's writings (1911-1997), especially those entitled Indonesia's history between the Myths: essays in legal history and historical theory (editions Indonesian language titled Bukan 350 Tahun Dijajah, publisher of Komunitas Bambu, Depok, published the year 1968). The work of an Indonesian historian born in Yogyakarta from a family of Dutch descent (his father came from a Dutch family who began to open a company and settled on the island of Java in the past century) and (his mother) Javanese (Sedyawati, 1997, p. 226) had provoked a number of comments experts, at least, like: Anthony Reid (Reid, 1968), Justus M. van der Kroef (van der Kroef, 1968), H. J. De Graaf (Graaf, 1969), and Harry J. Benda (Benda, 1970).

In general, the four experts considered that Resink's conclusion was a myth. In reality, territorial control by the Dutch did not occur in all area sovereignty and administration, which today is called Indonesia (van der Kroef, 1968). Even if there is, the concept of territorial sovereignty and administration is also not interpreted in a modern sense (Reid, 1968). What stated by Resink was also reported by several other historians (Graaf, 1969). However, Resink revealed it in a position outside the point of view of the power of the Dutch colonial government. It is, of course, more visible in its political and sociological side, compared to its legal aspects. This also causes it is not easy to understand Resink's work (Benda, 1970). 
What is clear, with the assumption of information on the arrival of the Dutch, even though initially "only" aimed at seeking wealth using trade was true, some regions (which today became the territory of Indonesia), they had been occupied. The Dutch first came to Indonesia in 1596, under the leadership of Cornelis de Houtman, and successfully landed at the Port of Banten (Parker, 2010, p. 23). Then, the second expedition of the Dutch to Indonesia was led by Jacob van Neck in 1598 (Carasso, 1985, p. 23) and they managed to land in Maluku in 1599 (Ricklefs, 1993, p. 27).

This article, of course, will not discuss the myth of the power of the Dutch colonial government for the entire territory of Indonesia in the modern sense. Because of this, among Indonesian historians, has been deemed complete (Hasbullah, 2017, p. 186). This article will only try to discuss a series of historical events, which, of course, because they are supported by various bibliographic sources, are believed actually to occur, so they are considered not myths. The series of historical events was the establishment of an organization which initially only had the purpose of protecting specific communities, namely Muslim traders in Solo and its surroundings, but immediately expanded to various cities in Indonesia (Rahardjo, 1993, p. 218).

The birth of the organization was then seen as a starting point for the shared awareness of the Indonesian people in fighting for their destiny, defending their dignity as a nation, and opposing the oppression of foreign countries and their compradors in the territory of Indonesia. The organization that fights based on Islamic principles and has the character of anti-imperialism, anti-capitalism, and anti-feudalism (Nasar, 2017, p. 2) is known as the Sarekat Dagang Islam (SDI). This article will discuss the background of its birth, its growth, and development, until its transformation into an organization that fought for Indonesian independence, namely Sarekat Islam (SI).

\section{B. METHOD}

This article was written using the literature survey method. This method is used to utilize library resources in obtaining data, tracking previous sources to prepare a theoretical framework and sharpen methodology (Zed, 2004, p. 1). Historical studies, generally rely on library research. It also applies to the study of Islamic history (organization) (Zed, 2004, p. 2). Islamic historians use library research to explain and deepen the answers to questions that have not been resolved in the past. Historical information on later published historical sources is seen as having the opportunity to provide a solution (Zed, 2004, p. 2). In this case, the explanation relates to the "Sarekat Dagang Islam (Islamic Trade Union) (1905-1911): among the Vereenigde Heritage Oostindische Compagnie (VOC) and Indonesian Independence" also obtained from these sources.

\section{RESULT AND DISCUSSION}

\section{Starting from the Arrival of the Vereenigde Oostindische Compagnie (VOC)}

If the Indonesian development calendar 500 years ago was reopened, the country now called Indonesia does not yet exist (Boediono, 2017, p. 27). History records, Indonesia at that time was still a region consisting of a collection of social-political units -in the form of the kingdom- with its level of sovereignty. Every kingdom controls territory, natural resources, and residents who are the foundation of its economic activities. It was these socio-political units which later became Indonesia (Assyaukanie, 2008, pp. xixxiii).

Nusantara, which means the sea studded with a range of islands (Zuhdi, 2002), is an open economic area. At that time, local economic activities were in the form of trade among them, even between other countries in Asia and Europe. It happens because the archipelago is located on a significant track by sea trade between Asia and Europe (Pramono, 2005, p. 108). The absence of a single political power that controls this region, such as in China or Japan, also makes it easier for anyone from outside to come and trade here. Indian, Chinese, Arabic, Indonesian (Malay), and later European (Dutch, Portuguese, English) traders initially carried out activities freely. They only need to pay attention to the rules of the authorities 
and local traditions for the continuity of their businesses. Over time, because of the superiority of the organization, technology, and access to market information from European traders dominated large trade, especially for the European route (Boediono, 2017, p. 28).

Chinese, Indian and Arab traders also play a role, but primarily only in trade activities between countries in the Asian region and within the archipelago. They also acted as intermediary traders with European traders (Oemar, Sudarjo, \& Suud, 1994, p. 83). Nusantara traders themselves played many roles in local trade and as a liaison between production centers and intermediary traders. In the next development, European traders who at that time were possessed by the spirit of conquering the new region - the soul of imperialism - began to use the superiority of their organizations and militaries to dominate the region territorially. They want to get higher profits than just ordinary trading. It is what Fuller hinted at regarding the greed of the Europeans in the form of colonialism in the East, which was mostly inhabited by Muslim communities (Fuller, 2010, pp. 5-17), as seen in the Dutch trading partnership in the Archipelago called Verenigde Oostindische Compagnie (VOC).

The VOC is a business entity formed by a group of investors in the Netherlands in the late 16th century with the primary goal of seeking profits (Peterson, Haykel, \& Heard-Bey, 2016, p. 134). Similar business entities were also formed in other European countries to look for profit. Over time, they are no longer satisfied with just the "normal" benefits that can be obtained by trading in Europe and established regions. They want bigger and fast profits.

In such an atmosphere, trading partners, such as VOC and EIC (the British East India Company) (Dijk, 2006, p. 5) are formed by investors who like high-profit business opportunities even though they are also at high risk. The main target of the trading partners is to control "new and underdeveloped" areas, especially producers of precious metals (gold, silver) and commodities that sell well in Europe (for example, spices). History notes that in subsequent developments, competition between businesses turned into a competition between countries to get new colonies, almost all governments or countries in Europe competed to expand their territories through diplomacy and war. Three centuries in the history of this world, the 17th to 19th centuries, was the peak of imperialist ideology namely the spirit of European countries to expand colonies to be exploited for the sake of the glory (and wealth) of the country (Northrop, 2014, p. 331).

VOC ships first arrived and landed in Banten in 1596 to buy merchandise, such as spices, to carry and sell in Europe. However, soon after, they did not just trade but intended to control the sources of production, directly or indirectly. They did it using "diplomacy," including fighting local authorities and, if they could not, use military force. That is what they did in stages, but systematically for two centuries since they set foot in the archipelago (Heidhues, 2003, p. 47).

At the end of the 18th century, the VOC's territory covered much of Java and Maluku as well as several trade posts in Sumatra, Kalimantan, and Sulawesi. With increasingly extensive territorial control, along with residents in it, the VOC gets new sources of income other than trade, namely taxes and various levies on residents in its territory (Dick, Houben, \& Lindblad, 2003, p. 15). By imposing taxes and other levies, the VOC has transformed from a mere trading partnership to a kind of "quasi-government" of a country (Boediono, 2017, p. 31).

There is a distinctive, intelligent-negative way, how this trade partnership with a limited number of personnel manages the territories it controls and those under its influence, namely by maximizing the role of local authorities and its bureaucracy (Arief \& Sasono, 1981, p. 77). This practice, with a more sophisticated version, continued until the Dutch colonial government in the 20th century. The VOC itself did not have the apparatus to carry out the levy. In carrying out the collection of taxes, the VOC relied on cooperation or through a subcontracting system with local authorities. Certain activities, such as the highly profitable levies on opium and levies on the trade in crops, were subcontracted to Chinese traders, who at that time had extensive networks in areas in Java (Boediono, 2017, p. 32). 
The "government" of the VOC era is an example of a system that is purely extractive, that is to use all business capabilities and public authority in his hands to absorb the economic surplus as much as possible from the area under his control. There is no consideration as to the fate of those who live there. In this system, there is no distinction between corporate authority and public authority, between business interests and the public interest, between the interests of employers and authorities. Everything is integrated and used to achieve one goal, which is to maximize economic surplus from the area - the extractive system of mummies. Concretely, at least, Indonesia's main attractions for VOCs are (Boediono, 2017, p. 35): (1) the abundance of land that could potentially be used as agricultural land; and (2) as well as the availability of cheap labor that is enough to work on it -two production facilities that are very rare in their home countries.

Around 1600, Indonesia's population was estimated at around 10 million, of which 4 million lived on Java and 2.5 million in Sumatra. Population growth during the time we discussed in this chapter is deficient, which averages around $0.2 \%$ per year. Birth rates are high but are offset by high mortality rates as a result of epidemics, hunger, war, and natural disasters (Boediono, 2017, p. 36). The deplorable condition of life in the zone between life and death, subsistence life - described by Thomas Robert Malthus (Boediono, 2017, p. 36) in his book, An Essay on the Principle of Population (1798), occurred in the Dutch colonies (Nusantara). (Malthus, 1803, p. 337). The VOC's harmful business policies, of course, gave birth to irony. Because, with this supposedly very effective system, the VOC eventually went bankrupt because of losses. In the late 18th century, all the assets and territories of the VOC were taken over by the Dutch government. Because of continuing losses, in 1799 the VOC was liquidated (Zanden \& Marks, 2013, p. 31).

\section{From the VOC to the Dutch East Indies Government}

\section{a. VOC Bankruptcy}

In 1800 , all assets and interests of the VOC were taken over and then managed directly by the Dutch government. It was the beginning of Indonesia officially becoming a Dutch colony. If colonialism was calculated from 1800, the Dutch colonial period was "only" a century and a half. This occupation also "only" occurred in regions that provided economic benefits to the Netherlands, not in all areas which today are the territory of Indonesia (Geppert \& Müller, 2016, p. 122).

With the acquisition of all VOC assets, gradually the pillars of a "state" (colony) were built which included the construction of a modern bureaucratic system, the legal system, the advanced financial system, and infrastructure networks. The 19th century was a period of consolidation of the colonial government system in Indonesia. The incorporation of the order of government was accompanied by systematic territorial consolidation as well (Abdullah, 2009, p. 91). In the early 20th century, de facto Dutch power encompassed the entire area that we now know as Indonesia (Boediono, 2017, p. 44).

This new system "colonial system" departed from the fundamental view that Indonesia was an integral part of the Kingdom of the Netherlands, of all time. The colonial economic system supported by the imperial system of government is a more modern, more efficient and more sustainable extractive system in absorbing economic surplus, and at the advanced stage there may be a human element, as seen in the "Ethical Politics." Since then, the government in the Indies has become an integral part of the government system and political system of the Kingdom of the Netherlands. In the Dutch cabinet, there was always a minister who was in charge of the Dutch East Indies and other colonies (Boediono, 2017, p. 45).

\section{b. Liberal Economic Policy in $\mathbf{1 8 7 0}$}

In the mid-19th century, there was an essential development in the Netherlands, namely the emergence of a government that adhered to the notion of liberalism which prioritized the rights and freedoms of individuals in social, economic and political activities. The change in the political atmosphere had 
significant consequences for economic life in the colonies. The Cultivation System, which is based on government monopolies, is removed and replaced with policies based on voluntary and open economic principles. The procedure taken was to open the width of the Dutch East Indies to private businesses and the government to limit itself to the functions of government (Sluyterman, 2014, p. 208).

In this new system, at least in principle, there is no longer any coercion to the people in carrying out their economic activities, including their land use and use of their workforce. All transactions and operations, once again in principle, are based on voluntary principles and free market mechanisms. In practice, various orders and coercion still occur at the level of farmers, plantations, and ordinary people (Wilson, Toms, Jong, \& Buchnea, 2016, p. 231).

The important milestone that marked this fundamental change was in 1870. In that year, two relevant laws were established, namely the Agrarian Law and the Sugar Law. The Agrarian Law allows private entrepreneurs to: (1) rent native land for paddy fields on an annual basis; and (2) obtain a 75-year concession from the government to use land that is not cultivated by residents (Boediono, 2017, p. 52).

With the legal system, government bureaucracy and finance that was established by the colonial government and the established network of infrastructure, this new policy attracted massive private investment to the Dutch East Indies. I. New plantation estates were opened in Java and Outside Java. Investors generally also use new cultivation techniques and technologies that are far more productive than those on smallholder plantations, which are the mainstay of the Cultivation System (1830-1870). Significant investments also go into the mining sector, and later even in the trade, finance, and manufacturing sectors (Boediono, 2017, p. 52).

Supported by reasonable export commodity prices, since the early 20th century until the depression of the world economy in 1930, the Dutch East Indies economy multiplied. The colonial economic system reached its golden age. The financial performance of the Dutch East Indies is recognized as one of the best in the world. The prosperity even "dripped" into the majority of the population of the Dutch East Indies. Life is good and orderly. Indonesian parents recall this period as "normal-age" or "'zaman-normal" (Boediono, 2017, p. 52).

\section{c. Ethical Politics in $1900-1930$}

The political shift in the Netherlands affected not only economic policy, but also government social policy in the Dutch East Indies. Since the first year of the 20th century, the so-called Ethical Politics was implemented. This policy was born due to the growth of public opinion in the Netherlands to "return the favor" to the population of the Dutch East Indies. The economic surplus generated during the Cultivation System has saved the Netherlands from bankruptcy. The reward was realized by several community welfare programs focused on three areas, namely "irrigation, education, and migration (transmigration)" (Jones, 2013, p. 39).

These programs were supported by the Dutch East Indies government budget, starting in 1901 and effectively implemented until about the mid-1920s, then continued to shrink and eventually stopped in the early 1930s because the funds provided were getting smaller. Through these Ethical Politics programs, a modem irrigation system was built in the main agricultural areas, new schools in several regions (quality, but very limited in number), and transmigration programs from Java began (which had started to be considered overpopulation) out of Java. However, these three Ethical Politics programs still benefited the Dutch colonial government. Indigenous people live within the limits of subsistence conditions. They still live in colonized states, all lacking and sad (Claver, 2014, pp. 133-240).

Although the scale was not massive and then continued to experience shrinkage, the policy of Ethical Politics had a significant impact on the lives of the inhabitants of the Indies. Educational programs spread the seeds of political awareness that will flourish later. In the early 20th century, national awareness grew and developed into a real political movement to achieve independent Indonesia (Hartono, 2014). The 
main driving force for the emergence of national consciousness is the educated people. Among them, there are products from the education system of the Ethical Politics program. Here we can note that the Dutch political development influenced the attitudes and policies of the Dutch East Indies government. It is also possible to include the downsizing decisions and finally the termination of the Ethical Political programs because the emergence of indigenous nationalist consciousness was considered to endanger the continuity of the Dutch colonial government in Nusantara (Susilo \& Isbandiyah, 2018).

\section{d. Worsening of People's Welfare}

It was noted earlier that although during the Forced Cropping System Java GDP continued to increase, the standard of living of Javanese people remained impoverished. What about the post-1870 period, when significant investments began to enter and were followed by a very substantial increase in export production? Is the population's welfare increasing? The answer is probably "yes" and "no." Several studies say that the standard of living of the majority of the population, especially since the Cultivation System was removed, has generally improved (Boediono, 2017, p. 57).

The population in Java and Outside Java grew very fast, reflecting not only improvements in health and infrastructure but also an increase in income of the people. The following table 1 supports this view. However, the table also shows that inequality between social groups also increases. A significant portion of the increase in the Dutch East Indies GDP (which is not recorded in the table) flows out during the Cultivation System as a slice system and in the liberal economic period as the proceeds of foreign investors (dominated by the Dutch) (Boediono, 2017, p. 57).

One study calculated that in the 1920s the money flowing out each year reached around $5 \%$ of the Netherlands Indies National Income, a large number compared to the experience of other countries.

Table-1

Average Household Income According to Ethnic Groups 1880-1925 (in Florin Per Year)

\begin{tabular}{cccc}
\hline \multirow{2}{*}{ ETHNIC GROUPS } & \multicolumn{2}{c}{ YEAR } & \multirow{2}{*}{ CHANGES } \\
& 1880 & 1925 & \\
\hline Indigenous & 146 & 201 & $38 \%$ \\
Asian Foreigner & 629 & 1.179 & $87 \%$ \\
European & 4.598 & 6.150 & $34 \%$ \\
Total & 163 & 270 & $66 \%$ \\
Gini Ratio & 0,39 & 0,48 & $0,09 \%$ \\
\hline \multicolumn{2}{c}{ Source: Boediono (Boediono, 2017, p. 58) }
\end{tabular}

The rest (recorded in Table 1) is distributed as income for residents in the Indies. Here a sensitive problem arises, namely the inequality of division between ethnic groups. A survey conducted in the 1930s showed that the average income level according to ethnic groups in the Indies was as follows (in guilders): Indigenous 59.70; China 326.90; European 2,700.00 (Boediono, 2017, p. 58)

This imbalance in the distribution of economic benefits between the colonies and the mothers of their countries and between ethnic groups in the settlement caused a sense of injustice among the educated population in the Indies (Boediono, 2017, p. 58). This condition then gave birth to a mass political 
movement that demanded Indonesian independence. This political movement started from the birth of the Islamic Trade Union (Sarekat Dagang Islam [SDI]).

\section{Birth of Sarekat Dagang Islam in 1905}

\section{a. Pre-Birth Conditions}

At the end of the 19th century or the beginning of the 20th century, it was reported that the domestic economy continued to deteriorate due to the ongoing global crisis. Economic conditions at that time continued to decline sharply; like the batik industry experienced tremendous financial difficulties. In the agricultural sector, crop yields were uncertain, and poor farmers were increasingly in debt to loan sharks or Chinese pawnshops. This situation forced Indonesia to import rice from Rangoon and Saigon. Not to mention the land rent system that strangles sugarcane farmers (Nasar, 2015). While ethnic Chinese people get a position of high economical profit. It is because the colonial government protected the foreign traders so that they could move freely in the economic field.

The Dutch government's policy in the social field has given birth to social classes in the community. It causes the Indonesian population to be divided into Indigenous, Asian, European groups. This condition resulted in the low dignity of the indigenous people under the foreign nation. With the expansion of private authorities, the role of the Chinese group in trade occupies a strategic position, especially in the export trade sector. The magnitude of the task of the Chinese group in this matter is indeed reasonable because, with the issuance of the Agrarian Law in 1870, it showed the limits of land ownership of the Chinese people. That is, only Chinese people are considered equal to the Dutch (Poespoprojo, 1984, p. 11).

Also, with the issuance of Decentralization of Wetoeving or the Decentralization Act (1903), it has allowed autonomy to take place along with the formation of several regional councils (Suradi, 1997, p. 9). Therefore, the position of the Chinese is not just a role in trade matters only, but also in terms of tax collection on certain roads made by the government (Resink, 1987, pp. 48-49). In 1900 the number of Chinese on the island of Java and Madura was 2,777,000. As a result of several economic fields controlled by Chinese traders, the condition of the people's economy was very bleak. This lousy situation also includes Indonesian batik traders in Surakarta City (Kutoyo, 1977, p. 277).

Besides in the social field, there is another effort from the Dutch colonial government, namely by using Zending politics, meaning an attempt by the Dutch East Indies government to Christianize the colonized nation. On this basis, the sense of togetherness of religion for those who are governed and governed can be achieved; this is merely an effort to strengthen their power in Indonesia. Because the Netherlands knows, the majority of the Indonesian people who are Muslim still have strong beliefs, that is, they cannot be governed by different religious governments (Benda, 1980, p. 44).

This condition shows the existence of a coalition between the Dutch colonial government and the Chinese people in the business. This condition encouraged Haji Samanhudi, a batik trader from Laweyan to the form of Sarekat Dagang Islam (from now on: SDI) Organization on the Sha'bān 16, $1323 \mathrm{H}$, Legi Monday, October 16, 1905 M, in Surakarta (Rofiq, 2016, p. 125).

This organization was initially a trade association and batik entrepreneur based on cooperatives. The aim is to advance Indonesian trade based on Islamic teachings. The development of SDI shows that this organization has long been desired by society in general, especially merchants and religious circles (Pringgodigdo, 1991, p. 5). With the establishment of SDI, H. Samanhudi was able to penetrate the game of the Dutch government.

With SDI, H. Samanhudi can deal directly with European importers and no longer through Chinese people. He did not buy batik raw materials from Chinese people. On the other hand, SDI also built equal cooperation with Chinese people in business organization, Kong Sing, in 1911. Collaboration with Chinese businesspeople made the Dutch East Indies government consider SDI a great danger to the 
existence and development of Dutch imperialism (Effendy, 2001, p. 524; Gonggong, 1975, p. 33; Mulyono \& Kutoyo, 1979, p. 39; Prabowo, 2011, p. 165; Wulandari, 2001, p. 35).

\section{b. Birth of SDI: Reviewing National Awakening Day}

The rise of SDI was the beginning of the success of the reform movement, the organizational system in Bumiputera, not just Islamic organizations. It is because a reform or a reform requires organizational resilience and continuity of the acquisition of funds. The actions of $\mathrm{H}$. Samanhudi and SDI are certainly very strategic. His revival efforts made the market an operating land and obtained funds to be able to maintain the sustainability of his organization. The progress of SDl's struggle in developing the economy of the people is inseparable from Islam which is used as a source of inspiration, source of movement, and ideological sources that can become the driving force of economic competition. As also quoted by Hamijaya, (Hamijaya, 2018), Abu Hanifa in his book Renungan Perjuangan Bangsa Dulu dan Sekarang (Reflections on the Struggle of the Nation in the Past and Present) (Hanifah, 1978, p. 19) wrote:
"Jadi resmi dalam bulan September 1906, H. Samanhudi memimpin gerakan rakyat yang dinamakan Sarekat Dagang Islam, yang dalam tempo singkat tidak saja bergerak di Jawa, tetapi juga di Sumatera, Kalimantan dan Sulawesi. Kebetulan memang di sinilah berada pedagang-pedagang pribumi beragama Islam yang berpengaruh dan cukup kuat untuk menentang hegemoni pedagang Tionghoa. Lama-kelamaan persaingan dengan pedagang Tionghoa menjadi seru dan terbuka. Sarekat Dagang Islam kesudahannya merupakan suatu gerakan nasional dan militan, sekalipun beragama Islam."
("It became official in September 1906, H. Samanhudi led a popular movement called Sarekat Dagang Islam (Islamic Trade Union), which in a short time not only moved on Java but also in Sumatra, Kalimantan and Sulawesi. Incidentally, it was here that indigenous Muslim traders were influential and robust enough to oppose the hegemony of Chinese traders. Over time the competition with Chinese traders became exciting and open. Sarekat Dagang Islam is the end of a national and militant movement, even though it is Muslim. ")

Making Islam an ideology, SDI is very quickly accepted by rural communities and experiences very rapid development. SDI was able to raise what had become public anxiety over various Dutch East Indies colonial policies which harmed them and regarded SDI as a means of self-defense against colonial rule (Hamijaya, 2018).

Under the conditions of the rise of the ulama through this activity, the Dutch Colonial Government sought to establish a rival organization. It is similar to rival Djamiat Choir, 13 Jumadil Awwal 1323, Monday Kliwon 1905 , on the advice of the Regent of Serang, PAA Djajadiningrat- Budi Oetomo organization was established, May 20, 1908. To rival SDI, the colonial government established an almost identical organization, Sarekat Dagang Islamiyah, 1909 in Bogor. The SDI-Bogor was established by the Dutch colonial government through Tirtoadisurjo, an OSVIA alumnus (Dutch Civil Service School).(Rofiq, 2016, p. 125)

\section{c. From Sarekat Dagang Islam (SDI) to Sarekat Islam (SI)}

Officially by the government, the National Awakening Day was calculated from May 20, 1908 (Rambe, 2008, p. 16), the date of the founding of the Budi Utomo association formed by a group of STOVIA Javanese Medical School students in Jakarta (Soedarmanta, 2007, p. 217). Precisely in the STOVIA Building which is now the National Awakening Museum Jln. Abdul Rahman Saleh No. 26 Jakarta. In 2015, the Indonesian people commemorated the 107th National Awakening Day. However, the national awakening is not a stand-alone event, but a chain of history. Since the occupation of foreign nations controlled the territory of the archipelago, resistance and rebellion took place in various regions even 
though they were local and regional (Suparman, 2012, p. 18). Among the crucial stages of the history of the National Awakening was the birth of SDI on October 16, 1905. Thus, the birth of SDI should be noted as "the pioneer of national awakening."(Nasar, 2017, p. 2).

SDI expanded its range of organizations to the outside of the city of Solo and reached outside the island of Java (Ardhana, 2005, p. 263). The first SDI congress was held in Solo in 1906. At this Congress, the name SDI changed to Sarekat Islam (SI). However, this change of name is not yet official, so the organization is still named SDI. The influence of SDI then developed and expanded to various regions in Indonesia (Kutoyo, 1977, p. 277). Islamic traders in Yogyakarta who are aware of the importance of the struggle against the colonialists of any nation immediately merge and actively take part in SDI (Kutoyo, 1977, p. 277). The establishment of SDI which has a strong influence is clearly based on economic considerations (Direktorat Jenderal Kebudayaan, 1977, p. 52).

Because Indonesian batik entrepreneurs generally embraced Islam, the Trade Union was called Sarekat Dagang Islam. In the case of the word "Islam," there is an identical meaning to the word "Indonesia" or the word "national." (Muljana, 2008, p. 121). The two last words ("Indonesia" or "National") are unknown to batik entrepreneurs who are generally only good at reading Arabic letters and Javanese. Thus the designation of "Islam" is more easily understood by its members and is more pervasive than the words "National" or the word "Indonesia." In the opinion of batik entrepreneurs, Chinese people are not Muslims. Thus the term "Islam" has shed resistance from the Indonesian side (strictly Java) against other groups, namely the Chinese (Muljana, 2008, p. 121).

In another perspective, in the period of the 1911 Chinese revolution, the Dutch government saw the existence of SDI and its partner, Kong Sing, increasingly endangering their interests (Ricklefs, 2008, p. 352). It is feared there will be a history of repetition, namely the formation of the Batavia Chinese collaboration with Soenan Mas (Sastrodiwiryo, 1994, p. 130). Therefore, the Dutch Government tried to pit SDI and Chinese merchants. The Dutch colonial government grew divisions by making it difficult for indigenous batik producers to obtain batik materials. With the complication of these materials, the Dutch government spread the news that the scarcity of batik materials was caused by the actions of Chinese traders. However, this effort was in vain, because indigenous and Chinese relations were even tighter, following a cooperation agreement to help each other between SI and Kong Sing in the event of oppression from the colonial government (Prabowo, 2011, p. 165).

The failure of their first provocation attempt, then the second method was taken. The colonial government created an anti-Chinese riot movement (Rozabi, 2013, p. 127). For this reason Laskar Mangkunegara was used to provoke the people to destroy Chinese shops (Prabowo, 2011, p. 165). This provocation caused riots in Surakarta and other cities. Nevertheless, the business failed again, after the people learned that the perpetrators of the destruction of the shops were Lakar Mangkunegara. Market activity returned as usual. However, to act legally, the organization must formulate its constitution to be legalized by the government.

After SDI has been running for several years, the movement is considered too narrow, because what is contained in it is only the traders (Kutoyo, 1977, p. 277). So the association, at Tjokroaminoto's suggestion, needed to expand its membership. In May 1912, three SI activists came to Tjokroaminoto's house to discuss. From the results of their discussion, Tjokroaminoto was willing to become the leader of SI. The event received the attention of SI management in Surakarta. Tjokroaminoto was invited to be available in Surakarta. At the time of his presence in Surakarta, May 13,1912, Tjokroaminoto received an honorary mandate, holding the leadership of SI previously held by $\mathrm{H}$. Samanhudi (Departemen Penerangan Republik Indonesia, 1989, p. 41).

The replacement of the leadership of SI was used by the Dutch, to re-fight the people. Laskar Mangkunegara was again used to create anti-Chinese riots in July 1912. Then a decision was made to suspend SI. With the suspension, a resistance reaction appears. The farmers of SI carried out a strike at 
the Krapyak Surakarta airport. The Surakarta Resident then realized that if the extended suspension would lead to uncontrolled riots. Therefore, they immediately revoked the suspension on August 26, 1912 (Fathoni, 2016)

The change in the name SDI to SI was formalized through a notary on September 10, 1912 (Dematra, 2013, p. 273). After becoming SI, this organization was able to gather hundreds of thousands of people in 1915. This organization fought for the standard of living of the natives and became the pioneer of the national movement (Noer, 2003, p. 91). Hadji Agus Salim explained that Islamic teachings had taught about anti-struggle capitalism, the struggle to defend the poor, the poor and insulted (Salim, 1996, p. 61).

From the description above, it can be concluded that the character of Indonesian National Awakening cannot be separated from the movement for economic improvement, eradicating poverty and injustice as practiced by the Sarekat Dagang Islam and Sarekat Islam in the past. Even the action to defend the poor became the starting point of the National Awakening. This organization has become a symbol of the Indonesian nation's resistance to the colonial economic system, which has resulted in poverty and destitution of the people (Rahardjo, 2010, p. 8).

According to Mohammad Hatta's testimony, although political associations were still banned by the laws of the colonial government, Sarekat Islam continued to expand its wings throughout Indonesia (Nasar, 2017 , p. 3). Hundreds of thousands of people from all groups could take shelter under the banner - the banner of Sarekat Islam, as if this union is a public hut, where all people complain about their complaints and uncover their guts (Nasar, 2017, p. 4).

The Islamic Sarekat Trade, which later changed into Sarekat Islam based its struggle on the principle of Islam and had the character of anti-imperialism, anti-capitalism, and anti-feudalism. The union that gathers the power of Muslims regardless of ethnicity or group moves the people to fight imperialism, capitalism, and feudalism (Nasar, 2017, p. 4). Sarekat Islam chooses religion as an active social binder so that it succeeds in attracting the lower class, farmers, and factory workers. Religious sense strengthened on a large scale, national sentiments and fostered a valid form of solidarity and encompassed various groups of activities (Djailani, 1985, p. 19).

The first SI Congress in 1916 was held in the city of Bandung (Sudiharto, Habsyah, \& Trihusodo, 2008, p. 132). This congress was deliberately used as an arena to maintain a unity demonstration of Muslims towards the unity of all indigenous Indonesians. Sarekat Islam firmly agreed to the idea of a male earth militia, but by proposing a condition that the government should also give the House of Representatives the Sarekat Islam which was initially founded on economic and religious considerations, in its first congress it had come forward with discussion of political matters. Since its first congress, Sarekat Islam has shown a pattern of national religious politics (Kutoyo, 1977, p. 278).

In its second congress, held in Jakarta in 1917, the Sarekat Islam emphasized its goal of obtaining selfgovernment (Muljana, 2008, p. 124). Through the House of Representatives, it was demanded that it be given legislative authority. Other than that, it was also proposed that the membership of the House of Representatives be expanded by appointing members representing non-political groups (Kutoyo, 1977, p. 278).

From the preceding description, it can be obtained an illustration, that religious-style organizations do not only fight for the development of their religion, but the struggle of the Islamic faith provides a strong foundation for the battle of the national movement against the oppression of invaders in all its forms (Ali, 1985, p. 30) The motivation of religion has a huge role in the struggle for national movements both in the political, economic, social, and cultural fields (Kutoyo, 1977, p. 278).

Margono Djojohadikusumo in his book Kenang-Kenangan Dari Tiga Zaman (1969), as quoted by Nasar (Nasar, 2015), notes that SI was indeed a mass organization, which was different from Budi Utomo or Indische Partij. Two essential figures, namely Hadji Agus Salim and H.O.S. Tjokroaminoto, is a force that 
drives SI. In Pringgodigdo's records, in Sedjarah Pergerakan Rakjat Indonesia (1960), other than Budi Utomo, SI, since its establishment was directed to ordinary people. The articles of association mention the purpose of SI, achieving real people's progress using brotherhood, unity, and help helping among all Muslims. Senior journalist Rosihan Anwar in the book Jatuh Bangun Pergerakan Islam di Indonesia (2011) asserted, "The pioneer of the nationalist movement that opposed colonialism and Dutch imperialism was Islam." In the eyes of Dr. Ernest Douwes Dekker, known as Dr. Setiabudi, "If there is no Islamic religion in Indonesia, Indonesian nationality will certainly disappear from these islands." (Nasar, 2015)

In a developing country, as it is running in Indonesia, the goals and objectives will be achieved if there is a balance between material and spiritual development (Schumann, 2004, p. 33). Reform efforts that do not pay attention to the balance between material elements and spiritual elements will result in an identity crisis (Yusuf, 2005, p. 80). Therefore, religion is an integral part of the life of the Indonesian people, (Bafadal, 2004, p. 169) because, without regard to religion, development in a country that is predominantly religious will undoubtedly face many problems (Gill, 2011, pp. 115-140).

Religion itself will flourish depending on the state of society and the current government. When an organization places faith as the basis and driver of community renewal, then it is also followed by the community to understand religion correctly, then the religion will develop well in the life of the nation and state (Kutoyo, 1977, p. 266). At the very least, that was the spirit inherited from the Islamic Sarekat Dagang, which later changed its name to Sarekat Islam.

\section{CONCLUSION}

From the explanation above, this article can conclude that the Sarekat Dagang Islam (SDI) was originally an association of indigenous Muslim traders. This organization, formed by $\mathrm{H}$. Samanhudi in Surakarta on October 16, 1905, was initiated with the initial aim of gathering indigenous Muslim traders (especially batik traders) to compete with big Chinese traders. His birth began with political discrimination set by the Dutch colonial government. With his sincerity, the role of the founder of this organization, H. Samanhudi, has succeeded in presenting a movement that is not only in the economic sphere but has an impact on the political struggle for independence. The impact on this political struggle became increasingly apparent when the Islamic Trade Society changed its name to Sarekat Islam on September 14, 1912. This article captures the historical message that the progress of a nation can only occur if the component of the country has shared awareness of development through national agreement or consensus formulation also done together.

\section{REFERENCES}

Abdullah, T. (2009). Indonesia: Towards Democracy. Singapore: Institute of Southeast Asian Studies.

Absiroh, U., Isjoni ', \& Bunari '. (2016). SEJARAH PEMAHAMAN 350 TAHUN INDONESIA DIJAJAH BELANDA. Jurnal Online Mahasiswa (JOM) Bidang Keguruan Dan Ilmu Pendidikan, 4(1), 1-15.

Aldrich, R. (1996). Greater France: A History of British Overseas Expansion. New York: Palgrave Macmillan.

Ali, F. (1985). Agama, Islam dan pembangunan. Jakarta: Pusat Latihan, Penelitian dan Pengembangan Masyarakat.

Altbach, P. G., \& Selvaratnam, V. (2012). From Dependence to Autonomy: The Development of Asian Universities. Dordrecht-Boston-London: Springer Science \& Business Media.

Aneek, C. (2010). International Relations Today: Concepts and Applications. Delhi-Chennai-Chandigarh: Pearson Education India. 
Anugrah, P. T. (2017). Bukti Indonesia Tidak Dijajah 350 Tahun. Program Studi Keamanan Maritim Fakultas Keamanan Nasional Bogor.

Ardhana, I. K. (2005). Penataan Nusa Tenggara Pada Masa Kolonial 1915-1950. Jakarta: RajaGrafindo Persada.

Arief, S., \& Sasono, A. (1981). Indonesia: ketergantungan dan keterbelakangan. Jakarta: Lembaga Studi Pembangunan.

Assyaukanie, L. (2008). Pengantar. In B. H. M. Vlekke, Nusantara: Sejarah Indonesia. Jakarta: Kepustakaan Populer Gramedia.

Axtell, J. (1987). Colonial America without the Indians: Counterfactual Reflections. The Journal of American History, 73(4), 981. https://doi.org/10.2307/1904058

Bafadal, F. A. (2004). Pemuda, agama, dan kehidupan kontemporer. Jakarta: Badan Litbang Agama dan Diklat Keagamaan.

Benda, H. J. (1970). Indonesia's History Between the Myths: Essays in Legal History and Historical Theory. By G.J. Resink. W. van Hoeve Publishers Ltd, The Hague 1968. Pp. xvi + 457. Notes, Bibliography, Glossary and Index. Price f36.50. Journal of Southeast Asian Studies, 1(2), 134136. https://doi.org/DOI: 10.1017/S0022463400020348

Benda, H. J. (1980). Bulan Sabit dan Matahari Terbit. Jakarta: Pustaka Jaya.

Bennett, B., \& Hodge, J. (2011). Science and Empire: Knowledge and Networks of Science across the British Empire, 1800-1970. Springer.

Boediono. (2017). Ekonomi Indonesia. Bandung: Mizan.

Bulhan, H. A. (2015). Stages of Colonialism in Africa: From Occupation of Land to Occupation of Being. Journal of Social and Political Psychology, 3(1), 239-256. https://doi.org/10.5964/jspp.v3i1.143

Carasso, D. (1985). A Short History of Amsterdam: A Survey of the City's History Illustrated from the Collections of the Amsterdam Historical Museum. Amsterdam: The Museum.

Cheng, S.-J. A. (2008). COLONIALISM. In R. T. Schaefer (Ed.), Encyclopedia of Race, Ethnicity, and Society. California: SAGE.

Claver, A. (2014). REDEFINING DUTCH-CHINESE COMMERCIAL RELATIONS (1890S-1910). In Colonial Relationships in Trade and Finance, 1800-1942. Dutch Commerce and Chinese Merchants in Java (pp. 133-240). Leiden: Brill. JSTOR.

Dei, G. J. S. (2007). The Denial of Difference: Reframing Anti Racist Praxis. In T. D. Gupta, C. E. James, R. C. A. Maaka, G.-E. Galabuzi, \& C. Andersen (Eds.), Race and Racialization: Essential Readings. Toronto: Canadian Scholars' Press.

Dematra, D. (2013). Mahaguru. Jakarta: Gramedia Pustaka Utama.

Departemen Penerangan Republik Indonesia. (1989). Indonesia 1989. Jakarta: Departemen Penerangan Republik Indonesia.

Dick, H., Houben, V. J. H., \& Lindblad, J. T. (2003). The Emergence of a National Economy: An Economic History of Indonesia, 1800-2000. Crows Nest: Allen \& Unwin.

Dijk, W. O. (2006). Seventeenth-century Burma and the Dutch East India Company, 1634-1680. Singapore: NUS Press. 
Direktorat Jenderal Kebudayaan. (1977). Sejarah Kebangkitan Nasional Daerah Istimewa Yogyakarta. Jakarta: Direktorat Jenderal Kebudayaan.

Djailani, A. T. (1985). The Background of Indonesia Nationalism. Mizan: Indonesian Forum for Islamic and Social Studies.

Effendy, M. (2001). Ensiklopedi Agama dan Filsafat. Palembang: Penerbit Universitas Sriwijaya.

Fathoni, R. S. (2016). Sarekat Islam - Sejarah Pergerakan Nasional. Retrieved 8 February 2019, from http://wawasansejarah.com/sarekat-islam/

Fuller, G. E. (2010). A World Without Islam. New York-Boston-London: Hachette UK.

Geppert, D., \& Müller, F. L. (2016). Sites of Imperial Memory: Commemorating Colonial Rule in the Nineteenth and Twentieth centuries. Manchester: Manchester University Press.

Gill, A. (2011). Secularization and the State. In D. Pollack \& D. V. A. Olson (Eds.), The Role of Religion in Modern Societies. New York-London: Routledge.

Gonggong, A. (1975). H.O.S. Cokroaminoto. Jakarta: Departemen Pendidikan dan Kebudayaan, Proyek Biografi Pahlawan Nasional.

Graaf, H. J. D. (1969). G. J. Resink: Indonesia's history between the myths: essays in legal history and hsitorical theory. [Translated by James S. Holmes.] (selected Studies on Indonesia, Vol. 7.) xviii 457 pp., 2maps. The Hague: W. Van Hoeve Publishers Ltd. for the Royal Tropical Institute, Amusterdam, 1968 Guilders 36.50. Bulletin of the School of Oriental and African Studies, 32(02), 437-438. https://doi.org/10.1017/s0041977x00055786

Hamijaya, N. (2018, January 29). Sarekat Dagang Islam, Titik Nol Perkumpulan Ekonomi di Laweyan. Retrieved 8 February 2019, from RILIS.ID website: http://rilis.id/sarekat-dagang-islam-titik-nolperkumpulan-ekonomi-di-laweyan?article_id=63367

Hanifah, A. (1978). Renungan Perjuangan Bangsa Dulu dan Sekarang. Jakarta: Yayasan Idayu.

Hartono, M. (2014). REALISASI POLITIK ETIS DI BOJONEGORO PADA AWAL ABAD XX: Kajian Sosial Ekonomi. ISTORIA: Jurnal Pendidikan Dan IImu Sejarah, 10(1), 1-22.

Hasbullah, M. (2017). Islam \& Transformasi Masyarakat Nusantara. Jakarta: Prenada Media.

Hawkins, M. (1997). Social Darwinism in European and American Thought, 1860-1945: Nature as Model and Nature as Threat. Cambridge: Cambridge University Press.

Heidhues, M. F. S. (2003). Golddiggers, Farmers, and Traders in the 'Chinese Districts' of West Kalimantan, Indonesia. New York: SEAP Publications.

Ingham, S. (2016). The Military Covenant: Its Impact on Civil-Military Relations in Britain. London-New York: Routledge.

Jackson, M. (2009). Neo-Colonialism, Same Old Racism: A Critical Analysis of the United States' Shift toward Colorblindness as a Tool for the Protection of the American Colonial Empire and White Supremacy. Berkeley Journal of African-American Law \& Policy, 11(1), 156-192.

Jones, T. (2013). Culture, Power, and Authoritarianism in the Indonesian State: Cultural Policy across the Twentieth Century to the Reform Era. Leiden: BRILL.

Kutoyo, S. (Ed.). (1977). Sejarah Daerah Daerah Istimewa Yogyakarta. Jakarta: Departemen Pendidikan dan Kebudayaan. 
Malthus, T. R. (1803). An essay on the principle of population: or, a view of its past and present effects on human happiness. London: Johnson.

Muljana, S. (2008). Kesadaran Nasional ; Dari Kolonialisme Sampai Kemerdekaan (Jilid 1). Yogyakarta: Lkis Pelangi Aksara.

Mulyono, \& Kutoyo, S. (1979). Haji Samanhudi. Jakarta: Departemen Pendidikan dan Kebudayaan, Pusat Penelitian Sejarah dan Budaya, Proyek Inventarisasi dan Dokumentasi Sejarah Nasional.

Nasar, M. F. (2015). Sarekat Dagang Islam dan Kebangkitan Nasional. Retrieved 7 February 2019, from jejakislam.net website: http://jejakislam.net/sarekat-dagang-islam-dan-kebangkitan-nasional/

Nasar, M. F. (2017). Islam dan Muslim di Negara Pancasila. Yogyakarta: Gre Publishing.

Newitt, M. (Ed.). (1986). The First Portuguese Colonial Empire. Exeter: University of Exeter Press.

Nieuwenhuys, R., \& Beekman, E. M. (1982). Mirror of the Indies: a history of Dutch colonial literature. Amherst: University of Massachusetts Press.

Noer, D. (2003). Islam \& politik. Jakarta: Yayasan Risalah.

Northrop, D. (2014). A Companion to World History. Malden-Oxford-West Sussex: John Wiley \& Sons.

Oemar, M., Sudarjo, \& Suud, A. (1994). Sejarah Daerah Jawa Tengah. Jakarta: Direktorat Jenderal Kebudayaan.

Parker, C. H. (2010). Global Interactions in the Early Modern Age, 1400-1800. New York: Cambridge University Press.

Peterson, J. E., Haykel, B., \& Heard-Bey, F. (2016). The emergence of the Gulf States: studies in modern history. London-Oxford-New York-New Delhi-Sydney: Bloomsbury.

Poespoprojo, W. (1984). Jejak-jejak Sejarah 1908-1926. Bandung: Remaja Karya.

Prabowo, A. J. (2011). Kebangkitan Islam. Yogyakarta: NFP Publishing.

Pramono, D. (2005). Budaya bahari. Jakarta: Gramedia Pustaka Utama.

Pratama, A. N. (2018, August 28). Benarkah Indonesia Dijajah Belanda Selama 350 Tahun? Kompas. Retrieved from https://nasional.kompas.com/read/2018/08/28/15540211/benarkah-indonesiadijajah-belanda-selama-350-tahun?page=all

Pringgodigdo, A. K. (1991). Sejarah Pergerakan Rakyat Indonesia (Cet. 10). Retrieved from https://trove.nla.gov.au/version/20852366

Rahardjo, M. D. (1993). Intelektual, inteligensia dan perilaku politik bangsa: risalah cendekiawan Muslim. Penerbit Mizan.

Rahardjo, M. D. (2010). Merayakan Kemajemukan Kebebasan Dan Kebangsaan. Jakarta: Kencana.

Rambe, S. (2008). Sarekat Islam pelopor nasionalisme Indonesia, 1905-1942. Yayasan Kebangkitan Insan Cendekia.

Reid, A. (1968). Indonesia's History between the Myths: Essays in Legal History and Historical Theory. Selected Studies on Indonesia, Vol. 7. By G. J. RESINK. Journal of the Humanities and Social Sciences of Southeast Asia, 124(4), 555-558. https://doi.org/10.2307/27860988

Resink, G. J. (1987). Raja dan Kerajaan Yang Merdeka di Indonesia. Jakarta: Djambatan. 
Ricklefs, M. C. (1993). A History of Modern Indonesia since c-1300. Hampshire: Macmillan International Higher Education.

Ricklefs, M. C. (2008). Sejarah Indonesia Modern 1200-2008. Jakarta: Penerbit Serambi.

Rofiq, A. C. (2016). Menelaah Historiografi Nasional Indonesia: Kajian Kritis terhadap Buku Indonesia dalam Arus Sejarah. Yogyakarta: Deepublish.

Rozabi, I. (2013). Percikan Api Sejarah. Malang: Universitas Brawijaya Press.

Salim, A. (1996). 100 tahun Haji Agus Salim. Jakarta: Pustaka Sinar Harapan.

Sastrodiwiryo, S. (1994). I Gusti Anglurah Panji Sakti, Raja Buleleng: 1599-1680. Jakarta: CV Kayumas Agung.

Schmidt-Nowara, C., \& Nieto-Phillips, J. M. (2005). Interpreting Spanish Colonialism: Empires, Nations, and Legends. Albuquerque: UNM Press.

Schumann, O. H. (2004). Menghadapi tantangan, memperjuangkan kerukunan. Jakarta: BPK Gunung Mulia.

Sedyawati, E. (1997). Sejarah Indonesia: penilaian kembali karya utama sejarawan asing. Jakarta: Pusat Penelitian Kemasyarakatan dan Budaya, Lembaga Penelitian, Universitas Indonesia.

Settles, J. D. (1996). The Impact of Colonialism on African Economic Development. University of Tennessee Honors Thesis Projects. Https://Trace.Tennessee.Edu/Utk_chanhonoproj/182. Retrieved from http://trace.tennessee.edu/cgi/viewcontent.cgi?article=1182\&context=utk_chanhon opro

Simpson, J. (2009). colony. In Oxford English Dictionary: Version 4.0; CD-ROM (2nd ed.). Oxford: Oxford University Press.

Sluyterman, K. E. (2014). Varieties of Capitalism and Business History: The Dutch Case. London-New York: Routledge.

Smith, W. D. (2012). The German Colonial Empire. North Carolina: UNC Press Books.

Soedarmanta, J. B. (2007). Jejak-jejak pahlawan: perekat kesatuan bangsa Indonesia. Jakarta: Gramedia Widiasarana Indonesia.

Steyn, P. (2003). Energy. In M. E. Page \& P. M. Sonnenburg (Eds.), Colonialism: An International, Social, Cultural, and Political Encyclopedia (Vol. 1). Santa Barbara-Denver-Oxford: ABC-CLIO, Inc.

Sudiharto, M., Habsyah, A., \& Trihusodo, P. (2008). Perjalanan Panjang Anak bumi. Jakarta: Yayasan Obor Indonesia.

Suparman. (2012). Pancasila. Jakarta: PT Balai Pustaka (Persero).

Suradi. (1997). Haji Agus Salim dan konflik politik dalam Sarekat Islam (Cet. 1). Jakarta: Pustaka Sinar Harapan.

Susilo, A., \& Isbandiyah, I. (2018). POLITIK ETIS DAN PENGARUHNYA BAGI LAHIRNYA PERGERAKAN BANGSA INDONESIA. HISTORIA Jurnal Program Studi Pendidikan Sejarah, 6(2), 403-416. https://doi.org/10.24127/hj.v6i2.1531

van der Kroef, J. M. (1968). Indonesia's History Between the Myths. Essays in Legal History and Historical Theory. By G. J. Resink. Pacific Affairs, 41(4), 617-619. 
Vandenbosch, A. (2001). The Netherlands-Indonesian Union. In P. H. Kratoska (Ed.), South East Asia, Colonial History: Independence through revolutionary war: Vol. VI. London-New York: Routledge.

Wilson, J., Toms, S., Jong, A. de, \& Buchnea, E. (2016). The Routledge Companion to Business History. London-New York: Routledge-Taylor \& Francis.

Wulandari, T. (2001). Sarekat Islam dan Pergerakan Politik di Palembang. Jakarta: Departemen Pendidikan Nasional.

Young, R. J. C. (2016). Postcolonialism: An Historical Introduction. West Sussex: John Wiley \& Sons.

Yusuf, M. Y. (2005). Ensiklopedi Muhammadiyah. Jakarta: RajaGrafindo Persada.

Zanden, J. L. van, \& Marks, D. (2013). An Economic History of Indonesia: 1800-2010. London-New York: Routledge.

Zed, M. (2004). Metode Penelitian Kepustakaan. Jakarta: Yayasan Pustaka Obor Indonesia.

Zuhdi, S. (2002). Sejarah Perkembangan Pelabuhan di Indonesia. In B. B. Utomo, S. Zuhdi, \& Widiati, Jejak-jejak Tinggalan Budaya Maritim Nusantara (pp. 8-17). Jakarta: Direktorat Jenderal Kebudayaan. 